\title{
The impact of market orientation on the development of relational capabilities and performance outcomes: The case of Russian industrial firms
}

\author{
Maria Smirnova $^{\text {a,* }}$, Peter Naudé ${ }^{b}$, Stephan C. Henneberg ${ }^{b}$, Stefanos Mouzas ${ }^{c}$, Sergei P. Kouchtch ${ }^{\text {a }}$ \\ a Graduate School of Management, St Petersburg State University Volkhovsky pereulok 3, 199004, Saint Petersburg, Russia \\ ${ }^{\mathrm{b}}$ Manchester Business School, Booth Street West, Manchester, M15 6PB, UK \\ c Department of Marketing, Lancaster University Management School, Lancaster LA1 4YX, UK
}

\section{A R T I C L E I N F O}

\section{Article history:}

Received 7 April 2009

Received in revised form 28 February 2010

Accepted 15 April 2010

Available online 27 October 2010

\section{Keywords}

Market orientation

Relational capabilities

Business performance

Russia

Industrial markets

\begin{abstract}
A B S T R A C T
The article investigates the role of market orientation as an antecedent for the development of relational capabilities and performance in Russian industrial firms. We test the direct role of different aspects of market orientation on business performance in comparison to an indirect and mediated influence via improving a firm's ability to become embedded in relational structures. The results of an empirical study demonstrate the differential impact of components of market orientation - customer orientation, competitor orientation, and interfunctional coordination - as direct and indirect antecedents of relational capabilities and thus subsequently of overall firm performance. It can be shown that in Russian industrial markets competitor orientation directly and positively impacts on performance, while the other two components of market orientation have only a mediated effect on performance via the development of relational capabilities.
\end{abstract}

(c) 2010 Elsevier Inc. All rights reserved.

\section{Introduction}

Market orientation has been discussed as an important organizational antecedent of business success (Han, Kim, \& Srivastava, 1999; Kohli \& Jaworski, 1990; Narver \& Slater, 1990), with innumerable studies testing its impact in different industries and countries (Akimova, 2000; Chan \& Ellis, 1998; Greenley, 1995; Kwon \& Hu, 2000). However, the mechanisms as to how the different aspects of market orientation (MO) achieve these positive outcomes are less well conceptualized; and virtually no research exists on understanding how MO works in non-Western environments, e.g. the transitional economies of BRIC (Brazil, Russia, India, China) (Akimova, 2000; Golden, Johnson, \& Smith, 1995; Greenley, 1995).

This article focuses therefore, firstly, on the potentially mediating effect of the development of relational capabilities which help companies build successful business relationships (Lorenzoni \& Lipparini, 1999; Sivadas \& Dwyer, 2000), and secondly, on the specific case of a transitional economy, i.e. Russia. Our objective is to investigate how different aspects of MO in Russian firms contribute towards the systematic development of relational capabilities aimed at supporting and enhancing business interactions and relationships with buying companies (Hallén, Johanson, \& Seyed-Mohamed, 1991; Ganesan, 1994; Araujo \& Mouzas, 1997). These business relationships

\footnotetext{
* Corresponding author. Tel.: + 781232384 48; fax: + 78123293234 . E-mail addresses: smirnova@gsom.pu.ru (M. Smirnova),Peter.Naude@mbs.ac.uk (P. Naudé), Stephan.Henneberg@dom01.mbs.ac.uk (S.C. Henneberg), s.mouzas@lancaster.ac.uk (S. Mouzas), kouchtch@gsom.pu.ru (S.P. Kouchtch).
}

are based on inter-firm cooperation which has become an important means of competing nationally as well as globally (Achrol, 1997; Achrol \& Kotler, 1999; Anderson, Håkansson, \& Johanson, 1994; Håkansson \& Ford, 2002; Uzzi, 1997). The advantages that a firm can gain from being embedded in business relationships and the wider business networks depends significantly on a firm's ability to manage within such complex relationships, i.e. a company's 'relational capabilities' (Ford, Gadde, Hakansson, \& Snehota, 2003; Möller \& Törrönen, 2003). In business-to-business markets, such relational capabilities not only serve as a guarantee of mutual understanding and benefits in customer relationships, but are also a source of relevant market knowledge, strategic flexibility, and effective process configuration (Webster, 1992; Hitt \& Borza, 2000; Jacob, 2006; Ma et al., 2009).

While research on relational capabilities of industrial companies has attracted some serious attention, the field is conceptually rather fragmented and not integrated into the central concept of MO (Dyer \& Singh, 1998; Day \& Van den Bulte, 2002; Jacob, 2006; Paulraj, Lado, \& Chen, 2008). The work of Day (1994) provides a conceptual starting point by emphasizing the link between market sensing capabilities (often linked with MO) and the firm's ability to coordinate customer linking and integration processes (Jacob, 2006). It can be argued that developing relational capabilities requires an understanding of the market in the wider business network, including the nature of stakeholder needs (Narver \& Slater, 1990). From the interaction and network perspective, MO can thus be seen as a pre-requisite for the creation of a firm's ability to initiate, develop and maintain successful interactions and relationships with business partners (Farrell, 
Oczkowski, \& Kharabsheh, 2008; Green, McGaughey, \& Casey, 2006; Nasution \& Mavondo, 2008; Racela, Chaikittisilpa, \& Thoumrungroje, 2007; Zhao \& Cavusgil, 2006). However, the impact of MO on business performance through the development of relational capabilities in industrial markets is so far mostly implied by existing research (Dyer \& Singh, 1998), with empirical confirmation being still insufficient (Jacob, 2006; Lorenzoni \& Lipparini, 1999).

This issue at hand is even more unclear in relation to firms operating in developing or transitional markets, such as Russia, where the marketing function is more in its infancy (Golden et al., 1995). Managing inter-firm relationships is strongly influenced by the ongoing process of transition, the changing business culture, and the interpersonal relationships that have traditionally dominated the Russian context of business interactions (Jansson, Johanson, \& Ramstroem, 2007; Johanson, 2008; Salmi, 2004). Thus, business relationships in Russia have been described as being characterized by high levels of instability, lack of information about potential partners, low information disclosure readiness, and the occurrence of opportunistic behavior (Halinen \& Salmi, 2001; Johanson, 2007). However, issues about managing such business relationships in transitional markets have started to attract some attention (Jansson et al., 2007; Salmi, 2004), but few examples of research exist which analyze antecedents and consequences of relational characteristics in these markets (Hitt \& Borza, 2000). Russia provides an appropriate case for examining these questions as it is comparable with other transitional markets in terms of instability, turbulence and unpredictability (Ramström et al., 2006).

Based on these issues, the objectives of our study are twofold. Firstly, using empirical data to test a nomological model, the research aims to analyze whether organizational attitudes, routines and practices linked to the MO concept affect building relational capabilities to enhance business relationships (Jacob, 2006; Möller \& Törrönen, 2003), and ultimately drive firm performance (Dyer and Singh, 1998). We thus contribute to clarifying the antecedents of relational capabilities, and the performance impact of MO. Secondly, the importance of MO and relational capabilities is investigated in the context of the Russian economy in which traditionally interpersonal relationships were seen as the most important determinant of business relationship success. Thus, for Russian industrial companies the impact of MO on organization-wide relational capabilities (beyond inter-personal aspects) is clarified (Foley \& Fahy, 2009; Hitt \& Borza, 2000; Hooley et al., 2000). As such, our analyses also contribute to the limited existing research on strategic orientations and capabilities of Russian firms (Golden et al., 1995).

The article is structured as follows: firstly, we will develop a model of market orientation and its impact on relational capabilities by parsimoniously deriving several hypotheses. As part of this discussion specific emphasis is given to the different concepts within the context of a transitional economy. After introducing our research method we present the empirical analysis and outline the resulting findings. A discussion of limitations, managerial implications, and further research concludes the article.

\section{Relational capabilities and market orientation}

The following part presents the theoretical foundations of the study and more specifically discusses existing foundations of research on relational capabilities and market orientation from the perspective of transitional economies. We pay particular attention to the construct of relational capabilities, while MO represents a rather better established construct in the research literature.

\subsection{Market orientation}

$\mathrm{MO}$ is one of the most central concepts in the marketing literature, starting from the 1990s onwards (Kohli \& Jaworski, 1990; Narver \&
Slater, 1990). The first key approaches to MO have focused on defining its subdimensions, especially regarding a behavioral operationalization (Kohli \& Jaworski, 1990; Narver \& Slater, 1990). For example, Kohli and Jaworski (1990) have linked MO to the "implementation of [the] marketing concept", which is being "reflected in activities and behaviors of an organization" (Kohli \& Jaworski, 1990, p. 1). Narver and Slater (1990) similarly focus on the components of MO and its potential effect on business performance. Later contributions have paid attention to the role of corporate culture in creating and implementing MO. For example, a customer orientation was used as being synonymous with MO in that it provides a "set of beliefs that puts the customer's interest first, while not excluding those of all other stakeholders such as owners, managers, and employees, in order to develop a long-term profitable enterprise" (Deshpande, Farley, \& Webster, 1993, p. 27). Further developments introduce organizational cooperation into MO definitions, e.g. Farley and Deshpandé (2005) outline MO as "the set of cross-functional processes and activities directed at creating and satisfying customers through continuous needs assessments" (p.14). During the later development of the construct a resource-based view as well as a capabilities perspective have attracted researchers' attention in revising the role of MO. Fahy et al. (2000) consider MO to be a key marketing capability. Other authors, for example Menguc and Auh (2006) and Day (1994), see MO as a firm-level resource, potentially leading to comparative advantage of the firm.

We follow in our research the conceptualization by Narver and Slater (1990) by focusing on three major components of MO: customer orientation, competitor orientation and interfunctional coordination. We do not use the behavioral conceptualization of MO as suggested by Kohli and Jaworski (1990) as our underlying nomological model posits the construct of relational capabilities as the central construct. Capabilities are influenced especially by the organizational culture and the orientation followed, as conceptualized in Narver and Slater's MO model. Considering orientations and attitudes as influencing factors of capabilities is in line with Foley and Fahy's (2004) and Verhoef and Leeflang's (2009) arguments which posit attitudinal aspects of MO as antecedents of capabilities development. Similar approaches have also been used relating to innovation capability (Akman \& Yilmaz, 2008; Han et al., 1999), firm-level dynamic capability (Menguc \& Auh, 2006, Yung-Ching \& Tsui-Hsu, 2006), organizational learning capability (Morgan, Katsikeas, \& Appiah-Adu, 1998), new product development capability (Baker \& Sinkula, 2005), and collaboration capability (Hyvönen \& Tuominen, 2007).

All of the three MO components of Narver and Slater (1990) have been used extensively in the marketing literature (Day, 1994; Deshpande et al., 1993; Han et al., 1999; Hunt \& Morgan, 1995; Morgan et al., 1998). Since "the heart of the market orientation is its customer focus" (Slater \& Narver, 1994, p. 22), customer orientation as the first component requires understanding not only the current needs of the customer, but also the whole value network of the customer, including customer's customer (Deshpande et al., 1993; Henneberg, Mouzas, \& Naudé, 2009, Rindfleisch \& Moorman, 2003). Competitor orientation as the second MO component provides the firm with an opportunity to benchmark and compare, e.g. with alternative suppliers (Armstrong \& Collopy, 1996; Day, 1994; Narver \& Slater, 1990; Zhou, Brown, Dev, \& Agarwal, 2007). Finally, interfunctional coordination relates to the involvement of personnel and other firm resources across the whole company in creating value for the customers and other stakeholders (Narver \& Slater, 1990; Ward et al., 2006; Wooldridge \& Minsky, 2002; Kahn \& Mentzer, 1998).

Numerous empirical studies have researched and supported the role that market orientation and its components play in improving firm performance, fostering innovativeness, and contributing to the creation of market-driven organizations (Day, 1994; Pelham, 1997; Vorhies, Harker, \& Rao, 1999). However, some contradictory research exists which shows only weak links between the constructs of MO and 
certain performance constructs (Greenley, 1995; Singh, 2003). However, the positive role of MO has been generally confirmed across different industries and countries, including some work undertaken in transitional economies (Bathgate, Omar, Nwankwo, \& Zhang, 2006; Farley \& Deshpandé, 2005; Hooley et al., 2000).

Thus, as part of our nomological model, we hypothesize in line with existing research that there will be a direct and positive impact of MO on firm performance in Russia. With regard to the three components of MO, they are all expected to act as a positive antecedent to performance. The first three hypotheses are:

H1a. The level of customer orientation of a firm is positively related to firm performance.

H1b. The level of competitor orientation of a firm is positively related to firm performance.

H1c. The level of interfunctional coordination a firm is positively related to firm performance.

\subsection{Understanding relational capabilities}

Relational capabilities have been discussed in many different contexts. However, no single accepted definition of the terms has been developed. Table 1 provides an overview of existing conceptualizations of relational capabilities.

There are a few common aspects in how existing research defines relational capabilities constructs. The first common element is a focus on accelerating knowledge access, supporting innovativeness and competitive advantage creation (Combe \& Greenley, 2004; Fahy et al., 2000; Lorenzoni \& Lipparini, 1999; Weerawardena \& O'Cass, 2004). Thus, higher relational capabilities imply that partners involved in business exchange can better acquire relationship-specific informa-

\section{Table 1}

Existing conceptualizations of relational capabilities in industrial markets.

\begin{tabular}{|c|c|}
\hline Authors & Conceptualization \\
\hline Day (1994) & $\begin{array}{l}\text { Customer linking capability - creating and managing } \\
\text { close customer relationships. }\end{array}$ \\
\hline $\begin{array}{l}\text { Day and Van } \\
\text { den Bulte (2002) }\end{array}$ & $\begin{array}{l}\text { Customer relating capability as a bundle of three } \\
\text { interrelated components: orientation, information } \\
\text { and configuration. }\end{array}$ \\
\hline Dyer and Singh (1998) & $\begin{array}{l}\text { Relational capability as the competitive advantage: } \\
\text { ability to forge, develop, and govern partnerships. }\end{array}$ \\
\hline Jacob (2006) & $\begin{array}{l}\text { Customer integration competency as a combination } \\
\text { of process configuration, communication and control } \\
\text { sub-dimensions. }\end{array}$ \\
\hline $\begin{array}{l}\text { Lorenzoni and } \\
\text { Lipparini (1999) }\end{array}$ & $\begin{array}{l}\text { Organizational ability to interact with other } \\
\text { companies (relational capability) that accelerate the } \\
\text { lead firm's knowledge access and transfer with } \\
\text { relevant effects on company growth and } \\
\text { innovativeness. }\end{array}$ \\
\hline Ma et al. (2009) & $\begin{array}{l}\text { Firm's ability to integrate these resources in form of } \\
\text { knowledge acquisition. }\end{array}$ \\
\hline $\begin{array}{l}\text { Möller and } \\
\text { Törrönen (2003) }\end{array}$ & $\begin{array}{l}\text { Capability to create additional value through } \\
\text { relational interfirm relationships. }\end{array}$ \\
\hline Paulraj et al. (2008) & $\begin{array}{l}\text { Inter-organizational communication as a relational } \\
\text { competency. }\end{array}$ \\
\hline $\begin{array}{l}\text { Rodríguez-Díaz and } \\
\text { Espino-Rodríguez (2006) }\end{array}$ & $\begin{array}{l}\text { Specific capabilities developed in the interfirm } \\
\text { relationships, which contribute to development of } \\
\text { interorganizational teams and integrated operating } \\
\text { routines, facilitation of information and knowledge } \\
\text { exchange. }\end{array}$ \\
\hline Sivadas and Dwyer (2000) & $\begin{array}{l}\text { Cooperative competency as an ability of interacting } \\
\text { units to adjust mutually, created through trust, } \\
\text { communication, coordination. }\end{array}$ \\
\hline Webster (1992) & $\begin{array}{l}\text { Relational capabilities as a result of broadening the } \\
\text { vision of relationships. Additional rents from } \\
\text { extremely close, long-term relationships between } \\
\text { companies and improve firm's competitive position } \\
\text { in the market. }\end{array}$ \\
\hline
\end{tabular}

tion and gain benefit through knowledge integration. Another common dimension of relational capabilities highlighted in the literature is improvement of firm's ability to communicate, coordinate and govern business interactions (Day \& Van den Bulte, 2002; Dyer \& Singh, 1998; Jacob, 2006; Paulraj et al., 2008). This aspect of relational capabilities has been further conceptualized and empirically tested (Day \& Van den Bulte, 2002; Jacob, 2006). For example, Jacob (2006) has developed a relational capability construct containing three key dimensions - process configuration capability, customer communication capability, and control capability. These dimensions measure a firm's ability to provide customized solutions for industrial customers as an indicator or relational capability. This approach is supported by Rodríguez-Díaz and Espino-Rodríguez (2006) who state that the development of relational capabilities leads to "integration of processes by related companies in such a way that greater integration means greater cooperation, higher commitment and trust, greater transfer of knowledge, greater innovation capability and a simplification or elimination of activities" (p. 489). Finally, relational capabilities are commonly associated with facilitating development of trust and reliance (Sivadas \& Dwyer, 2000; Baker, 1992), increasing trustworthiness within relationships and readiness for further collaboration.

Relational capabilities provide a specific issue in the context of business interactions in transitional economies such as Russia. Several studies have focused on understanding firm behavior and the role of business culture in forming relationship practices in Russia (Ayios, 2004; Salmi, 2004). These have reinforced the view that the role of interpersonal relationships remains as important now as it was in Soviet time. This creates a unique feature of the Russian economy: there often exists insufficient trust or reliance among the firms, while high levels of trust nevertheless exist on an interpersonal level (Butler \& Purchase, 2008). Farley and Deshpandé (2005) point in this context to the fact that firms in business-to-business markets in the Soviet time had a "supplier orientation" with the "customer absorbing almost all risk as well as tolerating poor quality and irregular delivery" (p. 7). It has been argued that within a centrally planned economy, as long as a firm accepted the plan, there was no need for firms to pay attention to planning interactions with business partners in a systematic way (Johanson, 2008). However, after the dissolution of the planned economy, the increased resource dependencies as part of market exchanges linked to business relationships have required the development of capabilities to understand the market as well as customers and competitors, and also to serve industrial customers by providing them with customized solutions (Jacob, 2006). Companies had to create new identities and positions within business networks, reinforcing the development of capabilities to match mutual activities through exchanges and interactions (i.e. 'plan matching') (Johanson, 2007). The changes which occurred could arguably have led to a rebalancing of the system, emphasizing the development of organization-wide relational capabilities over interpersonal capabilities.

Following the logic of business relationships culture development in Russia, it is important to investigate not only the ability to interact effectively with business partners as part of a collaborative relationship due to knowledge and experience at the interpersonal level (Mikhailitchenko \& Lundstrom, 2006; Salmi, 2004), but rather to analyze the firms' organization-wide competences, in the case of our research the relational capabilities based on the adaptation of routines, process configuration, communication systems, and control mechanisms (Jacob, 2006).

For the purpose of this study, we therefore adopt the approach developed by Jacob (2006) in conceptualizing relational capabilities as a three-component construct. As stated above, this conceptualization of relational capabilities has already been empirically tested, and it allows analyzing the structural approach to developing relational capabilities by incorporating key subdimensions and their level of development in a firm. This approach also incorporates Day's (1994) understanding of customer-linking capability as the competence to 
create and manage close customer relationships, requiring a higher level of coordination and participation in joint activities as well as close communication between partners. We thus capture the knowledge exchange component of relational capabilities as well as the communication component within our definition.

\subsection{The role of relational capabilities as a mediating construct}

Besides the hypothesized direct effect of MO on firm performance, our nomological model tests a mediating effect via the construct of relational capabilities. Foley and Fahy (2009) stress the importance to understand the role of MO within a capabilities framework. While they see a reciprocal relationship between MO and capability development, our model uses a unidirectional relationship between these constructs by linking MO to relational capabilities.

The construct of relational capabilities as encompassing the organizational resources which enable interorganizational communication, knowledge exchange, and tailored interactions can be argued to be of pivotal importance in situations of complexity, uncertainty and dynamic market environment, as exemplified by the changing market structures in transitional economies. Such complexity has been argued to cause 'collapsing capabilities' (Atuahene-Gima, 2005). Relational capabilities are thus seen as qualifying the importance of hitherto significant competences, e.g. interpersonal relationships in the case of Russia. MO contributes to a heterogeneous collection of customer and competitor related information which can help firms in transitional economies to analyze, process, and integrate environmental trends (Ma et al., 2009). Another feature of the transitional economy is the role of interactions and networks as compensating for the lack of market-supporting institutions (Salmi, 2004). Teece, Pisano, and Shuen (1997) state in this context that in rapidly changing environments "there is obviously value in the ability to sense the need to reconfigure the firm's asset structure and to accomplish the necessary internal and external transformation" (p. 520). This relational capability (i.e. reconfiguring a firm's asset structure vis-àvis external forces) leads to the requirement to first understand transactional or relational needs of external stakeholders (Coviello, Brodie, Danaher, \& Johnston, 2002). This is driven by developing a customer orientation (Mason \& Harris, 2006; Narver \& Slater, 1990), thus we hypothesize:

H2a. The level of customer orientation of a firm is positively related to relational capabilities of a firm.

Similarly, the role of competitor orientation becomes more important in cases when the competitive intensity increases in the marketplace, as happened in Russia as part of the transition process (Dwairi, Bhuian, \& Jurkus, 2007; Ma, Yao, \& Xi, 2009). Understanding competitors can help the firm to re-organize and improve their own business processes, and to develop and re-configure internal resources, to improve the firm's competitiveness and ability to compete with the other market players (Rodríguez-Díaz \& Espino-Rodríguez, 2006). Hooley et al. (2000) argue that firms with higher market orientation will follow a more aggressive, externally focused approach (via developing relational capabilities), and will aim to strongly differentiate their offer from that of competitors (Kale, Singh, \& Perlmutter, 2000). Therefore, closer attention to competition will enable the firm to develop capabilities to better manage in important business relationships. We hypothesize that:

H2b. The level of competitor orientation of a firm is positively related to relational capabilities of a firm.

The construct of interfunctional coordination refers to the degree to which the functions and departments within the firm communicate and interact with each other (Auh \& Menguc, 2005; Kahn \& Mentzer,
1998; Kohli \& Jaworski, 1990; Narver \& Slater, 1990). Narver and Slater (1990) point to the fact that every department and function can theoretically contribute to the creation of higher value for customers and other stakeholders. Indeed, Wind and Robertson (1983) have argued for the contribution of other functions besides marketing to be incorporated into a firm's marketing strategy. The danger of low internal alignment (i.e. lack of interfunctional coordination) has been argued by Atuahene-Gima (2005), who stresses the negative effect of the phenomenon of 'internal stickiness' which occurs when market knowledge accumulates only within specific departments in a firm. Norms around interfunctional coordination have substantial impact on the nature of firms' ability to manage cooperative relationships, and empirical results indicate that firms with cooperative interdepartmental relationships are more inclined to build interfirm collaboration (Campbell, 1998).

One of the key aspects of interfunctional coordination is the multifaced capturing, and then sharing and dissemination of market knowledge (Day, 1994). Due to the fact that the concept of relational capabilities includes process re-configuration in order to improve business relationships and the embedded position of the firm in the overall business network, interfunctional coordination represents a key antecedent. For example, Lai, Pai, Yang, and Lin (2009) have found that the combination of customer and supplier market orientation significantly affects relationship learning. We thus hypothesize that coordination between functions can stimulate not only learning within relationships, but does also develop the incorporation of market knowledge into processes and capabilities aimed at fostering collaborative business interactions.

H2c. The level of interfunctional coordination of a firm is positively related to relational capabilities of a firm.

\subsection{Relational capabilities and firm performance}

According to Lorenzoni and Lipparini (1999) there exists insufficient empirical evidence regarding the link between relational capabilities and firm performance, despite the growing literature on interfirm relationships. However, most existing studies stress that for firms with high relational capabilities, superior benefits are expected. Specifically, Rodríguez-Díaz and Espino-Rodríguez (2006) argue that a particular competitive advantage, i.e. associative advantage, is created through interactions with business partners and can only be achieved and sustained if firms develop dynamic capabilities to be able to continue such business relationships in the face of environmental changes. In cases of relationship dissolution, relational capabilities cannot immediately be reused and may be lost (Teece et al., 1997). Similarly, Dyer and Singh (1998) show that a relational advantage is created through the development of relational capabilities, and define it as "a supernormal profit jointly generated in an exchange relationship that cannot be generated by either firm in isolation and can only be created through the joint idiosyncratic contributions of the specific alliance partners" (p. 662). Similarly, Jacob (2006) considers market success as a direct outcome of the firm's ability to integrate customer interaction in its organizational routines.

Based on these arguments in the literature, we hypothesize that those firms which have created relational capabilities in the organization aimed at a better customer integration and coordination of interfirm relationships, will also have superior business results:

H3. The level of relational capabilities is positively related to firm performance.

Thus, the overall nomological model (see Fig. 1) compares parsimoniously the direct effect of different components of MO on firm performance with the indirect effect based on MO fostering relational capabilities which in turn positively affect the success of the 


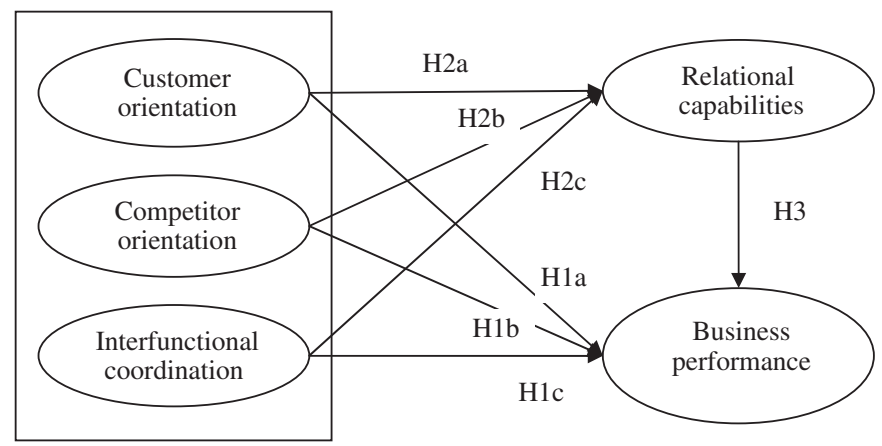

Fig. 1. Model of proposed hypotheses.

firm. Seven hypotheses cover the different facets of the model. This nomological model provides the basis for an empirical test with industrial firms in Russia.

\section{Research design}

\subsection{Data collection}

In order to test the model and the hypotheses, a survey was conducted. The questionnaire for the survey was developed on the basis of existing scales (see Table 3 ), which were initially verified as relevant for the Russian context by a pool of academic experts. Based on the existing measurement models in the literature for all five key constructs, individual question items were translated and backtranslated, and then pre-tested with a sample of ten executives of Russian firms, operating in industrial markets (packaging materials distribution, material production, and metal construction; all interviews were in Russian) to ensure the question wording was clear and relevant in a Russian industrial context. Once the questionnaire was finalized, industrial firms from multiple regions of Russia were contacted. Those companies which agreed to participate in the study were subsequently visited in person, and the questionnaire was filled in the presence of the interviewer. Data was collected via a stratified sample by region, industry, and company size to ensure that the structure of Russian firms operating in industrial markets was represented in our data. The main data collection was conducted in the period between December 2007 and March 2008, using identified key respondents (CEOs, CMOs, Marketing SVPs). With each respondent two meetings were arranged: during the first meeting the first section of the questionnaire was delivered that covered questions regarding MO and performance, during the second meeting the second section was used which related to questions about relational capabilities. This procedure allowed for minimizing the effects of common method bias (Podsakoff, MacKenzie, Lee, \& Podsakoff, 2003). We contacted 479 industrial firms from 34 regions in Russia, of whom $33 \%$ (158 companies) participated in the study.

The average age of respondents was 40.9 years, with an average working experience in their current firm of 9.6 years (5.5 years in their current position). The respondents were mostly men (73.4\%), and they specified that they were mostly in 'strategic management' (51.9\%) or 'marketing' (32.9\%). Table 2 provides key information on the industry structure of the sample as well as distribution of sample firms on annual sales, firm size and type of business.

\subsection{Construct measures}

The constructs used in the study were measured using multi-item scales (five-point Likert-type scales, mostly anchored in 'strongly agree' to 'strongly disagree'). All constructs used reflective measurement models (Diamantopoulos \& Siguaw, 2006; Diamantopoulos \& Winklhofer, 2001). The scale properties were evaluated using
Table 2

Sample description companies.

\begin{tabular}{lr}
\hline Key industries (\%) & \\
Machinery & 26.1 \\
Production of construction materials & 14.0 \\
Chemical industry & 9.6 \\
Appliance manufacturing & 7.6 \\
Packaging & 7.0 \\
Telecommunications & 6.4 \\
Food industry & 5.1 \\
Woodworking industry & 5.1 \\
Other & 19.1 \\
Type of business (\%) & 75.9 \\
Product & 24.1 \\
Service & \\
Annual sales 2006 (m USD) & 28.3 \\
Less than 1.5 & 20.3 \\
$1.5-3$ & 24.6 \\
3-15 & 26.8 \\
More than 15 & \\
Number of employees & 10.4 \\
Less than 50 & 13.5 \\
From 50 to 100 & 33.8 \\
From 100 to 500 & 19.0 \\
From 500 to 1000 & 23.3 \\
More than 1000 & \\
\hline
\end{tabular}

traditional psychometric approaches. Reliability and uni-dimensionality of the scales were assessed, e.g. using item-to-total correlations (Anderson \& Gerbing, 1988). Some items were dropped (indicated in Table 3 ) as a result of confirmatory factor analysis (CFA) due to crossloading (all multi-dimensional analyses were done with AMOS 7.0). To check for uni-dimensionality of constructs each of the scales was tested separately and a joint factor analysis was conducted.

The three constructs for MO, i.e. customer orientation, competitor orientation, and interfunctional coordination, were measured using the original Narver and Slater (1990) scale items. These scales had already been successfully tested previously for transitional economies (Hooley et al., 2000). A CFA confirmed the three factor solution for market orientation, establishing the independence of the three different components: $\chi^{2}=.852(p=0.736), \quad \mathrm{RMR}=0.037$, $\mathrm{GFI}=0.961, \mathrm{AGFI}=0.937, \mathrm{CFI}=1.000, \mathrm{RMSEA}=0.000(p=0.980)$.

The relational capabilities construct was measured by applying the measurement scales developed by Jacob (2006) for a sample of German industrial firms. The construct included four items. The construct was tested for uni-dimensionality, and a single factor structure was confirmed. The CFA fit indeces are $\chi^{2}=1.176$ $(p=0.3086), \mathrm{RMR}=0.008, \mathrm{GFI}=0.993, \mathrm{AGFI}=0.964, \mathrm{CFI}=0.999$, $\operatorname{RMSEA}=0.034(p=0.440)$.

The business performance construct was measured as a second order construct via three subconstructs (growth, adaptability, and customer satisfaction) proposed by Venkatraman (1989) and applied by Vorhies and Harker (2000) (see Table 3). Each of them addresses a firm's performance over the last three years. The growth subconstruct measures the firm's relative market share growth and sales growth in comparison to the main competitors. The second subconstruct adaptability - relates to the number of new products, the introduction of the new products to the market, and the time-to-market. The customer satisfaction subconstruct also includes delivering value to customers. These business performance items were measured on a fivepoint Likert-type scale (anchored in -2 to +2 , and in 'much worse than the main competitors' and 'much better than the main competitors'). Again, CFA was applied to test the three-factor structure of the business performance construct. The measurement model provided good fit for the expected three-factor structure: $\chi^{2}=1.729(p=0.110)$, $\mathrm{RMR}=0.009, \mathrm{GFI}=0.985, \mathrm{AGFI}=0.948, \mathrm{CFI}=0.995, \mathrm{RMSEA}=0.057$ $(p=0.357)$. Thus, the final structural model included the construct of business performance as a second order construct based on three first order constructs growth, adaptability, and customer satisfaction. 
Table 3

Scale items for theoretical measures.

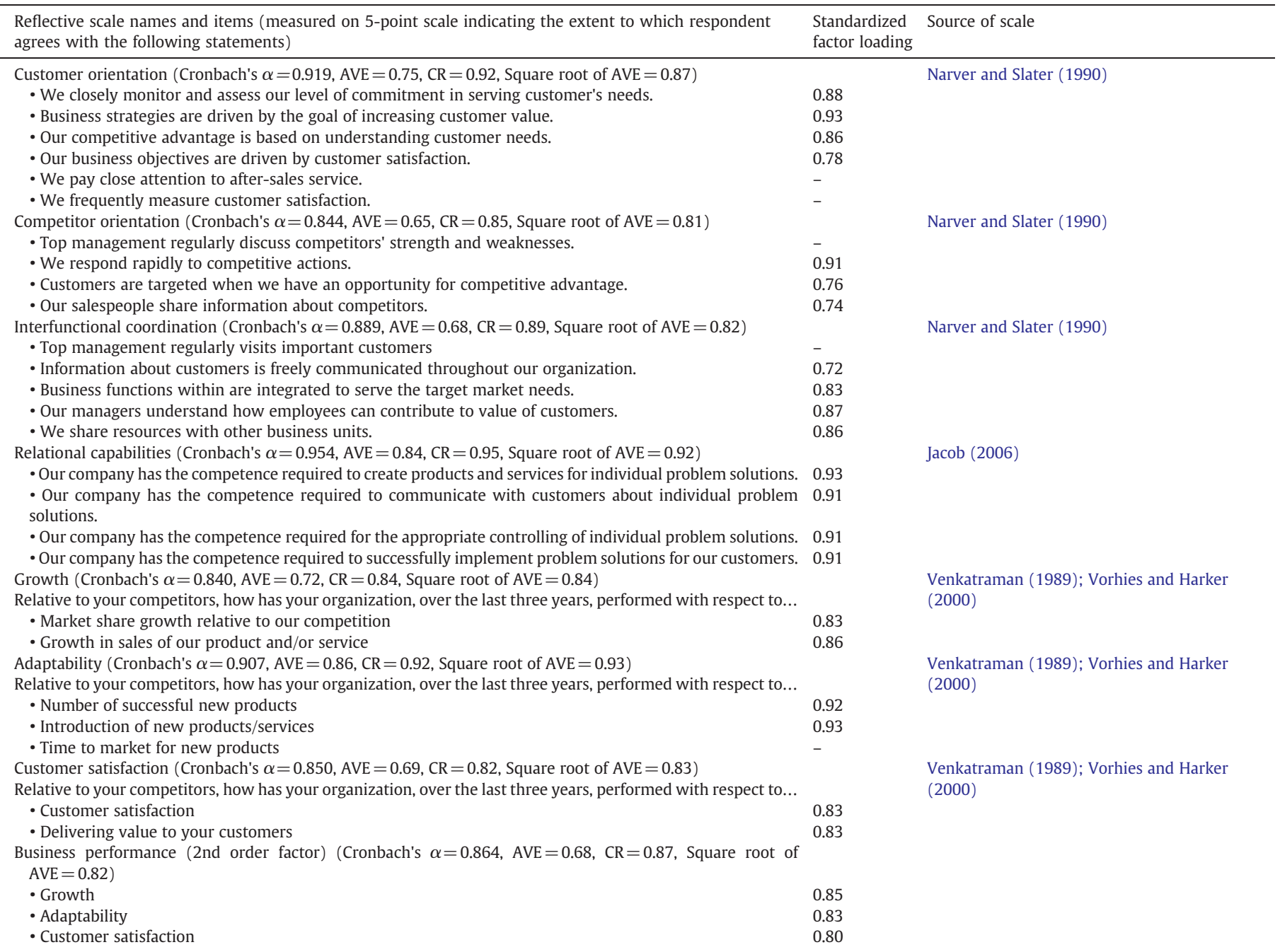

(Note: $\mathrm{AVE}=$ Average variance extracted; $\mathrm{CR}=$ Construct reliability; $-=$ items deleted during the model estimation stage).

\subsection{Quality tests}

We tested the measurement models for the constructs via an overall CFA, using the fit indices suggested by Joreskog and Sorbom (1999) and Kline (2005). The estimates of the CFA demonstrate a reasonable model fit: $\mathrm{RMR}=0.045, \mathrm{GFI}=0.905, \mathrm{AGFI}=0.869$, $\mathrm{CFI}=0.986, \quad \mathrm{RMSEA}=0.040 \quad(p=0.792)$, with $\chi^{2}=1.253$ ( $p=0.030$ ) becoming significant mainly due to the small sample size.

Table 3 provides information regarding the different constructs and the items used. Cronbach's $\alpha$ for all constructs were above 0.84 , with individual item factor loading all exceeding the 0.7 cut-off point (implying a shared variance of at least $50 \%$ between item and construct; items below this cut-off point were eliminated from the final data analysis) (Hulland, 1999). In all cases the average variance extracted (AVE) exceeds the critical level of 0.5 (the lowest level is 0.65) (Fornell \& Cha, 1994), and all composite reliability scores exceeds the critical level of 0.7 (the lowest level is 0.82) (Fornell \& Larcker, 1981). To evaluate the discriminant validity of the constructs, we examine whether the communalities of the AVE measures for any two constructs exceed their squared correlations. As this condition is fully satisfied (see Table 4), discriminant validity can be assumed (Fornell \& Cha, 1994; Fornell \& Larcker, 1981). Table 5 shows the construct data characteristics.

\section{Analysis}

To test the different hypotheses against the structural model, we used covariance-based path estimation, namely structural equation modeling based on the Maximum Likelihood method. The overall fit measures show a good fit of the model: $\chi^{2}=1.151(p=0.119)$, $\mathrm{RMR}=0.044, \mathrm{GFI}=0.908, \mathrm{AGFI}=0.874, \mathrm{CFI}=0.991, \mathrm{RMSEA}=0.031$ $(p=0.930)$.

Our aim was to understand the role of different components of MO in driving business performance, specifically whether or not the effect of MO on outcome variables is direct or mediated via the construct of relational capabilities. Our path estimations (see Fig. 2) show that with regard to direct effects only one of the three components of MO

Table 4

AVE and squared correlation matrix.

\begin{tabular}{llllll}
\hline Variable & 1 & 2 & 3 & 4 & 5 \\
\hline 1. Customer orientation & $\mathbf{0 . 7 5}$ & & & & \\
2. Competitor orientation & 0.25 & $\mathbf{0 . 6 5}$ & & & \\
3. Interfunctional coordination & 0.32 & 0.46 & $\mathbf{0 . 6 8}$ & & \\
4. Relational capabilities & 0.23 & 0.19 & 0.22 & $\mathbf{0 . 8 4}$ & \\
5. Business performance & 0.13 & 0.18 & 0.07 & 0.16 & $\mathbf{0 . 6 8}$
\end{tabular}

Note: Bold numbers on the diagonal show the AVE. Numbers below the diagonal represent squared construct correlations. 
Table 5

Means, standard deviations and correlations of the constructs.

\begin{tabular}{|c|c|c|c|c|c|c|c|}
\hline Constructs & Mean & $\begin{array}{l}\text { Standard } \\
\text { deviation }\end{array}$ & 1 & 2 & 3 & 4 & 5 \\
\hline $\begin{array}{l}\text { 1. Customer } \\
\text { orientation }\end{array}$ & 4.31 & 0.77 & 1 & & & & \\
\hline $\begin{array}{l}\text { 2. Competitor } \\
\text { orientation }\end{array}$ & 3.55 & 0.95 & $0.464^{* *}$ & 1 & & & \\
\hline $\begin{array}{l}\text { 3. Interfunctional } \\
\text { coordination }\end{array}$ & 3.73 & 0.95 & $0.527^{* *}$ & $0.583^{* *}$ & 1 & & \\
\hline $\begin{array}{l}\text { 4. Relational } \\
\text { capabilities }\end{array}$ & 3.76 & 1.05 & $0.479^{* *}$ & $0.479^{* *}$ & $0.446^{* *}$ & 1 & \\
\hline $\begin{array}{l}\text { 5. Business } \\
\text { performance }\end{array}$ & 0.56 & 0.69 & $0.358^{* *}$ & $0.319^{* *}$ & $0.240^{* *}$ & $0.372^{* *}$ & 1 \\
\hline
\end{tabular}

*** Correlation is significant at the $p<0.01$ level (2-tailed).

has a significant effect on firm performance. While the relationships between customer orientation and interfunctional coordination on the one hand, and firm performance on the other are non-significant (it is also noteworthy that the path coefficient for hypothesis H1c is in fact negative), competitor orientation has a relatively strong and positive effect on business performance $(0.355$, with a $p<0.01)$, thus supporting H1b.

For the pathways between MO and relational capabilities the structural equation model produced the following results: both customer orientation and interfunctional coordination have a positive impact on the development of relational capabilities (coefficients of 0.291 and 0.204 ). However, while H2a can be supported with a very high level of confidence $(p<0.01), \mathrm{H} 2 \mathrm{c}$ is indicating a lack of significance with a $p$-level $<0.1$. The impact of competitor orientation H2b was not significant. Thus, the level of the firm's orientation towards gathering information on competitors has no influence on the level of the firm's relational capabilities.

Hypothesis H3 tested the impact of relational capabilities on business performance. As expected the impact is significant and positive, with a path coefficient of $0.256(p<0.01)$. Thus, firms which have undertaken investments and adaptation to create customeroriented processes and specific capabilities to support customer integration, do achieve better overall performance.

Therefore, while only one construct of MO (competitor orientation) has a direct impact on firm performance, the other two nevertheless also contribute positively to organizational outcomes. However, customer orientation and interfunctional coordination work through building relational capabilities which in turn drives firm performance. This mediated effect of two components of MO means that the direct effect of competitor orientation (coefficient of 0.355 ) is complemented by the indirect (mediated) effects of customer orientation and interfunctional coordination on business

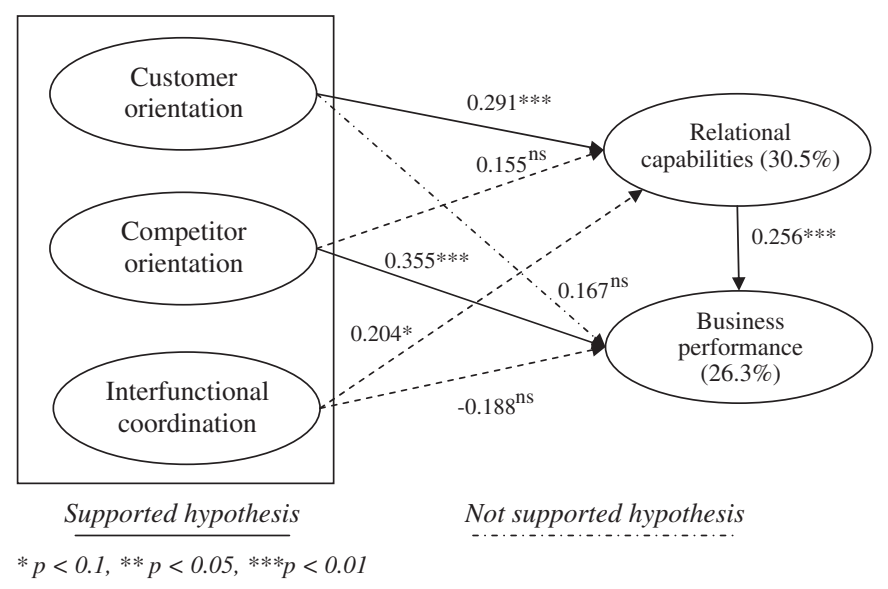

Fig. 2. Path estimations. performance (coefficient $0.13=0.291^{*} 0.256+0.204^{*} 0.256$ ), giving a combined and strong positive impact of $\mathrm{MO}$ on firm performance of 0.48. In summary, the model explains considerable amounts of variance for the two dependent constructs, relational capabilities (30.5\%) and business performance (26.3\%).

\section{Discussion and implications}

This study investigated the relationship between different aspects of a market orientation on the one hand, and performance implications for firms on the other. Specifically, the question as to whether MO has direct or indirect effects on business outcomes in the Russian context forms the key contribution. Indirect or mediating effects were tested via including the construct of relational capabilities which represent a company's abilities to foster collaborative business relationships. Therefore, this study contributes to a better understanding of the link between the different components of market orientation and firm performance by identifying that both direct as well as indirect positive influences (via the development of relational capabilities) exist in the case of Russian industrial firms. As such, these findings on the one hand support existing research concerning the positive results of MO for transitional economies (Akimova, 2000; Ellis, 2005; Fahy et al., 2000; Farley \& Deshpandé, 2005). On the other, they also qualify this research by showing that in Russia only MO aspects which are aimed at developing a competitor orientation have direct positive outcomes for the firm. This is in line with findings on transitional economies which emphasize the importance of marketsensing abilities (Appiah-Adu, 1998; Singh, 2003). However, our results show that positive aspects relating to market sensing in Russia are not so much about developing a customer orientation, but mainly about understanding competitors' actions. This result therefore contributes to our understanding of the specifics of Russian industrial firms which is reflected in adaptation to the characteristics of the Russian transitional economy, specifically by exploiting opportunities via extensive growth strategies vis-à-vis competitors (Gurkov, 2009). However, a customer orientation does also contribute to firm performance in the Russian context, but only in a mediated way via building relational capabilities, i.e. organizational routines and processes which help a company to develop and sustain collaborative business relationships.

The ratio between direct and indirect effects of MO on performance is about 2:1 in Russian industrial firms. As such, the clarification of these different direct and indirect effects of MO addresses a research need articulated by, for example, Hooley et al. (2000). Our results specifically qualify the central role that the creation of a customer orientation plays for the success of a firm in building successful business relationships and development of firm's embeddedness in business context (Day \& Van den Bulte, 2002; Deshpande et al., 1993; Rindfleisch \& Moorman, 2003) by showing that in case of Russia, this effect is not dominant and only plays a material role via the development of relational capabilities. We also provide evidence for the importance of building capabilities that foster inter-firm relationships and thus contribute to closing a research gap identified by Lorenzoni and Lipparini (1999).

The analysis of the role of interfunctional coordination in Russian industrial firms provides us with some counterintuitive results. Existing studies which were mostly tested in Western research settings suggest that interfunctional coordination should be a vital element for improving firm's performance and capabilities. However, the Russian data provides non-significant or only very tentative impact on business performance and relational capabilities, respectively. This finding provides rich potential for further research. Our results may be explained by the sporadic nature of interfunctional coordination in Russian firms, or a lack of systematization of internal interaction and the reactive nature of activities in cases where interaction is needed. Especially older (i.e. established) Russian firms 
may follow a more formalized approach, based on more traditional hierarchies (Salmi, 2004) and less on horizontal interconnections between functions, while it may be interesting to understand if newer firms might start up with more highly developed interfunctional links with a clearer direct impact on firm performance (Shirokova, 2009).

The implications of our results provide researchers with a deeper understanding of the importance that both $\mathrm{MO}$ and the organizational mechanisms set up to improve relational capabilities have in determining levels of business performance. We believe that it points to the need for subsequent research to focus on developing both a better understanding of the sub-dimensions of MO as well as how to develop relational capabilities in both transitional and developed economies.

\section{Managerial implications}

The Russian economy is still perceived as a black box by many businessmen aiming to enter this market. As Child and Faulkner state "when one of the partners ... comes from an emerging country and the other from a highly developed economy, their configuration of objectives ... will almost certainly differ from that in the case of partners from two developed markets" (1998: p. 297). The level of market orientation and relational capabilities, aimed at the development of interfirm cooperation, and the integration of processes among the firms in industrial markets, can be the language that will help the firms to understand each other and find mutually beneficial solutions (Farley \& Deshpandé, 2005; Johanson, 2008). We believe that differences in the levels of market orientation and relationship capabilities of Russian firms will determine their ability to collaborate with other market players and so remain competitive in a market open to global competitors (Cadogan, Cui, \& Li, 2003).

Our results have three specific implications for managers. The first area of managerial concern focuses on developing a competitor orientation. Our results show this to be important in directly affecting business performance. But, like customer orientation, there has not been a high need for competency in this area due to the former central planning, thus, there is some leeway to developing such skills and resources. With the freeing up of the economy, there will be more competition from both local and also multinational competitors, implying a greater need to monitor business network activities ( $\mathrm{Ma}$ et al., 2009).

The second implication centers on the role that customer orientation and interfunctional coordination have in influencing business performance through the mediating role of relational capabilities. It is our contention that it is the first of these, customer orientation that needs to be managers' main area of focus. Our data shows that customer orientation is statistically more significant than interfunctional coordination. Customer orientation is a skill that a highly planned economy did not require (Farley \& Deshpandé, 2005); thus, Russian managers can use this as a lever to enhance their firms' ability to interact within business networks by building relational capabilities. Developing such relational skills represents the third implication: as we have argued above, in a planned economy personal relationships played an important role. With a freer hand in deciding with whom to do business, managers within Russian companies need to develop their own abilities to interact with economic counterparts not just learning to interact 'better,' but also learning to chose better i.e. identifying those potential partners that can enhance business performance the most (Butler \& Purchase, 2008).

We conclude that investments in the development of organizational routines, aimed at improving these customer interactions, and better relationships capabilities are indeed paying off for Russian firms. A commitment to implementing such orientations and capabilities indicates a long-term orientation and supports evidence of the changing nature of interfirm relationships in Russia's industrial markets (Johanson, 2008; Salmi, 2004). Future research in Russia needs to concentrate on the conceptualization and measurement of market orientation and relational capabilities aimed at interactions with multiple stakeholders, not just customers (Greenley, Hooley, Broderick, \& Rudd, 2004; Greenley, Hooley, \& Rudd, 2004). Such a research direction could provide a more comprehensive picture of organizational interactions in both developed and transition economies.

\section{References}

Achrol, R. S. (1997). Changes in the theory of interorganizational relations in marketing: Toward a network paradigm. Journal of the Academy of Marketing Science, 25(1), 56-71.

Achrol, R. S., \& Kotler, P. (1999). Marketing in the network economy. Journal of Marketing, 63(Special Issue), 146-163.

Akimova, I. (2000). Development of market orientation and competitiveness of Ukranian firms. European Journal of Marketing, 34(9/10), 1128-1248.

Akman, G., \& Yilmaz, C. (2008). Innovative capability, innovation strategy and market orientation: An empirical analysis in Turkish software industry. International Journal of Innovation Management, 12(1), 69-111.

Anderson, J. C., \& Gerbing, D. W. (1988). Structural equation modeling in practice: A review and recommended two-step approach. Psychological Bulletin, 103, 411 -423.

Anderson, J. C., Håkansson, H., \& Johanson, J. (1994). Dyadic business relationships within a business network context. The Journal of Marketing, 58(4), 1-15.

Appiah-Adu, K. (1998). Market orientation and performance: Empirical tests in a transition economy. Journal of Strategic Marketing, 6, 25-45.

Araujo, L. M., \& Mouzas, S. (1997). Competition and cooperation in vertical marketing systems. In H. G. Gemunden, H. Germunden, T. Ritter, \& A. Walter (Eds.), Relationships and Networks in International Markets (pp. 145-165). Ney York: Pergamon Press.

Armstrong, J. S., \& Collopy, F. (1996). Competitor orientation: Effects of objectives and information on managerial decisions and profitability. Journal of Marketing Research, 33(2), 188-199.

Atuahene-Gima, K. (2005, October). Resolving the capability-rigidity paradox in new product innovation. Journal of Marketing, 69, 61-83.

Auh, S., \& Menguc, B. (2005). Top management team diversity and innovativeness: The moderating role of interfunctional coordination. Industrial Marketing Management, $34(3), 249-261$.

Ayios, A. (2004). Trust and Wester-Russian business relationships. Aldershot: Ashgate.

Baker, W. (1992). The Network Organization in Theory and Practice. In Nitin Nohria, \& Robert G. Eccles (Eds.), Networks and Organizations: Structure, Form and Action. Boston, MA: Harvard Business School Press.

Baker, W. E., \& Sinkula, J. M. (2005). Market orientation and the new product paradox. Journal of Product Innovation Management, 22, 483-502.

Bathgate, I., Omar, M., Nwankwo, S., \& Zhang, Y. (2006). Transition to a market orientation in China: Preliminary evidence. Marketing Intelligence and Planning, 24 (4), $332-346$.

Butler, B., \& Purchase, S. (2008). Use of social capital among Russian managers of a new generation. Industrial Marketing Management, 37, 531-538.

Cadogan, J. W., Cui, C. C., \& Li, E. K. Y. (2003). Export market-oriented behavior and export performance. International Marketing Review, 20(5), 493-513.

Campbell, A. J. (1998). Do internal departmental relationships influence buyers' expectations about external supply partnerships? Journal of Business $\mathcal{E}$ Industrial Marketing, 13(3), 199-214.

Chan, H. N., \& Ellis, P. (1998). Market orientation and business performance: Some evidence from Hong Kong. International Marketing Review, 15(2), 119-139.

Child, J., \& Faulkner, D. (1998). Strategies of cooperation: Managing alliances, networks and joint ventures. Oxford: Oxford University Press.

Combe, I. A., \& Greenley, G. E. (2004). Capabilities for strategic flexibility: A cognitive content framework. European Journal of Marketing, 38(11/12), 1456-1480.

Coviello, N. E., Brodie, R. J., Danaher, P. J., \& Johnston, W. J. (2002). How firms relate to their markets: An empirical examination of contemporary marketing practices. Journal of Marketing, 66(3), 33-46.

Day, G. S. (1994). The capabilities of market-driven organization. Journal of Marketing, $58,37-52$.

Day, G. S., \& Van den Bulte, Ch. (2002). Superiority in customer relationship management: Consequences for competitive advantage and performance. Report No. 02-123. Cambridge, MA: Marketing Science Institute.

Deshpande, R., Farley, J. U., \& Webster, E. F., Jr. (1993). Corporate culture, customer orientation, and innovativeness in Japanese firms: A quadrad analysis. Journal of Marketing, 57, 23-27.

Diamantopoulos, A. \& Siguaw, J. A. (2006). Formative versus reflective indicators in organizational measure development: A comparison and empirical illustration. British Journal of Management, 17(4), 263-282.

Diamantopoulos, A., \& Winklhofer, H. M. (2001). Index construction with formative indicators: An alternative to scale development. Journal of Marketing Research, 38 (2), 269-277.

Dyer, J. H., \& Singh, H. (1998). The Relational View: Cooperative Strategy and Sources of Interorganizational Competitive Advantage. Academy of Management Review, 23 (4), 660-679.

Dwairi, M., Bhuian, S. N., \& Jurkus, A. (2007). Revisiting the pioneering market orientation model in an emerging economy. European Journal of Marketing, 41(7/8), 713-721. 
Ellis, P. D. (2005). Market orientation and marketing practice in a developing economy. European Journal of Marketing, 39(5/6), 629-645.

Fahy, J., Graham, H., Cox, T., Beracs, J., Fonfara, K., \& Snoj, B. (2000). The development and impact of marketing capabilities in Central Europe. Journal of International Business Studies, 31(1), 63-81.

Farley, J. U., \& Deshpandé, R. (2005). Charting the evolution of Russian firms from Soviet "producer orientation" to contemporary market orientation. Journal of Global Marketing, 19(2), 7-26.

Farrell, M. A., Oczkowski, E., \& Kharabsheh, R. (2008). Market orientation, learning orientation and organizational performance in international joint ventures. Asia Pacific Journal of Marketing and Logistics, 20(3), 289-308.

Foley, A., \& Fahy, J. (2004). Towards a further understanding of the development of market orientation in the firm: A conceptual framework based on the marketsensing capability. Journal of Strategic Marketing, 12, 219-230.

Foley, A., \& Fahy, J. (2009). Seeing market orientation through a capabilities lens. European Journal of Marketing, 43(1/2), 13-20.

Ford, D., Gadde, L. E., Hakansson, H., \& Snehota, I. (2003). Managing Business Networks. Chichester: John Wiley.

Fornell, C., \& Cha, J. (1994). Partial Least Squares. In R. P. Bagozzi (Ed.), Advanced Methods of Marketing Research (pp. 52-78). Cambridge, MA: Blackwell.

Fornell, C., \& Larcker, D. F. (1981). Evaluating structural equation models with unobservable variables and measurement error. Journal of Marketing Research, 48, $39-50$.

Ganesan, Sh. (1994). Determinants of Long-Term Orientation in Buyer-Seller Relationships. Journal of Marketing, 58, 1-19.

Golden, P. A., Johnson, D. M., \& Smith, J. R. (1995). Strategic orientation and marketing strategies in transition economies: A study of Russian firms. Journal of Strategic Marketing, 3, 1-22.

Green, K. W., McGaughey, R., \& Casey, K. M. (2006). Does supply chain management strategy mediate the association between market orientation and organizational performance? Supply Chain Management: An International Journal, 11(5), 407-414.

Greenley, G. E. (1995). Market orientation and company performance: Empirical evidence from UK companies. British Journal of Management, 6, 1-13.

Greenley, G. E., Hooley, G. J., Broderick, A. J., \& Rudd, J. M. (2004). Strategic planning differences among different multiple stakeholder orientation profiles. Journal of Strategic Marketing, 12(3), 163-182.

Greenley, G. E., Hooley, G. J., \& Rudd, J. M. (2004). Market orientation in a multiple stakeholder orientation context: Implications for marketing capabilities and assets. Journal of Business Research, 58, 1483-1494.

Gurkov, I. (2009). Strategy process as formulation and realization of corporate goals: the synthesis of surveys in Russian firms. Journal for East European management studies, 14(1), 48-64.

Håkansson, H., \& Ford, D. (2002). How should companies interact in business networks? Journal of Business Research, 55(2), 133-139.

Halinen, A., \& Salmi, A. (2001). Managing the informal side of business interaction: Personal contacts in the critical phases of business relationships. Proceedings, 17th IMP conference, Oslo, Norway.

Hallén, L., Johanson, J., \& Seyed-Mohamed, N. (1991, April). Interfirm adaptation in business relationships. Journal of Marketing, 55, 29-37.

Han, J. K., Kim, N., \& Srivastava, R. K. (1999). Market orientation and organizational performance: Is innovation a missing link? Journal of Marketing, 62, 30-45.

Henneberg, S. C., Mouzas, S., \& Naudé, P. (2009). Going beyond customers - A business segmentation approach using network pictures to identify network segments. Journal of Business Market Management, 3(2), 91-113.

Hitt, L., \& Borza, A. (2000). Partner selection in emerging and developed market contexts: Resources-based and organizational learning perspectives. Academy of Management Journal, 43(3), 449-467.

Hooley, G., Cox, T., Fahy, J., Shipley, D., Beracs, J., Fonfara, K., \& Snoj, B. (2000). Market orientation in the transition economies of Central Europe: Tests of the Narver and Slater market orientation scales. Journal of Business Research, 50, 273-285.

Hulland, J. (1999). Use of Partial Least Squares (PLS) in strategic management research: A review of four recent studies. Strategic Management Journal, 20(2), 195-204.

Hunt, S. D., \& Morgan, R. M. (1995). The comparative-advantage theory of competition. Journal of Marketing, 59, 1-15.

Hyvönen, S., \& Tuominen, M. (2007). Channel collaboration, market orientation and performance advantages: Discovering developed and emerging markets. International Review of Retail and Distribution and Consumer Research, 17(5), 423-445.

Jacob, F. (2006). Preparing industrial supplies for customer integration. Industrial Marketing Management, 35, 45-56.

Jansson, H., Johanson, M., \& Ramstroem, J. (2007). Institutions and business networks: A comparative analysis of the Chinese, Russian, and West European markets. Industrial Marketing Management, 36, 955-967.

Johanson, M. (2007). Networks in transition. Proceedings, 23rd IMP-conference, Manchester, UK.

Johanson, M. (2008). Institutions, exchange and trust: A study of the Russian transition to a market economy. Journal of International Management, 14, 46-64.

Joreskog, K. G., \& Sorbom, D. (1999). LISREL 8: User's Reference Guide. Chicago, IL: Scientific Software.

Kahn, K., \& Mentzer, J. (1998). Marketing's integration with other departments. Journal of Business Research, 42(1), 53-62.

Kale, P., Singh, H., \& Perlmutter, H. (2000). Learning and protection of proprietary assets in strategic alliances: Building relational capital. Strategic Management Journal, 21, $217-237$.

Kline, R. B. (2005). Principles and practice of structural equation modeling. New York: The Guilford Press.
Kohli, A., \& Jaworski, B. J. (1990, April). Market-orientation: The construct, research propositions, and managerial implications. Journal of Marketing, 54, 1-18.

Kwon, Y., \& Hu, M. Y. (2000). Market orientation among small Korean exporters International Business Review, 9, 61-75.

Lai, C. -S., Pai, D. -C., Yang, C. -F., \& Lin, H. -J. (2009). The effects of market orientation on relationship learning and relationship performance in industrial marketing: The dyadic perspectives. Industrial Marketing Management, 38, 166-172.

Lorenzoni, G., \& Lipparini, A. (1999). The leveraging of interfirm relationships as distinctive organizational capability: A longitudinal study. Strategic Management Journal, 20(4), 317-337.

Ma, X., Yao, X., \& Xi, Y. (2009). How do interorganizational and interpersonal networks affect a firm's strategic adaptive capability in a transition economy? Journal of Business Research, 62(11), 1087-1095.

Mason, K. J., \& Harris, L. C. (2006). Market orientation emphasis: An exploration of macro, meso and micro factors. Marketing Intelligence and Planning, 24(6), $552-571$.

Menguc, B., \& Auh, S. (2006). Creating a firm-level dynamic capability through capitalizing on market orientation and innovativeness. Journal of the Academy of Marketing Science, 34(1), 63-73.

Mikhailitchenko, A., \& Lundstrom, W. J. (2006). Inter-organizational relationship strategies and management styles in SMEs: The US-China-Russia study. Leadership E' Organization Development Journal, 27(6), 428-448.

Möller, K., \& Törrönen, P. (2003). Business suppliers' value creation potential. A capability-based analysis. Industrial Marketing Management, 32, 109-118.

Morgan, R. E., Katsikeas, C. S., \& Appiah-Adu, K. (1998). Market orientation and organizational learning capabilities. Journal of Marketing Management, 353-381.

Narver, J. C., \& Slater, S. F. (1990, October). The effect of a market orientation on business profitability. Journal of Marketing, 20-35.

Nasution, H. N., \& Mavondo, F. T. (2008). Organizational capabilities: Antecedents and implications for customer value. European Journal of Marketing, 42(3/4), 477-501

Paulraj, A., Lado, A. A., \& Chen, I. J. (2008). Inter-organizational communication as a relational competency: Antecedents and performance outcomes in collaborative buyer-supplier relationships. Journal of Operations Management, 26, 45-64.

Pelham, A. M. (1997). Market orientation and performance: The moderating effect of product and customer differentiation. Journal of Business E' Industrial Marketing, 12 (5), 276-296.

Podsakoff, P. M., MacKenzie, S. B., Lee, J. Y., \& Podsakoff, N. P. (2003). Common method biases in behavioral research: A critical review of the literature and recommended remedies. The Journal of Applied Psychology, 88(5), 879-903.

Racela, O. C., Chaikittisilpa, C., \& Thoumrungroje, A. (2007). Market orientation, international business relationships and perceived export performance. International Marketing Review, 24(2), 144-163.

Rindfleisch, A., \& Moorman, C. (2003). Interfirm cooperation and customer orientation. Journal of Marketing Research, 40(4), 421-436.

Rodríguez-Díaz, M., \& Espino-Rodríguez, T. F. (2006). Developing relational capabilities in hotels. International Journal of Contemporary Hospitality Management, 18(1), 25-40.

Salmi, A. (2004). Institutional change of business networks: Russian transition revisited. Proceedings, 20th IMP conference, Copenhagen, Denmark.

Shirokova, G. V. (2009). Organisational life-cycle: The characteristics of developmental stages in Russian companies created from scratch. Journal for East European Management Studies, 14(1), 65-85.

Singh, S. (2003). Effects of transition economy on the market orientation-business performance link: The empirical evidence from Indian industrial firms. Journal of Global Marketing, 16(4), 73-95.

Sivadas, E., \& Dwyer, F. R. (2000). An examination of organizational factors influencing new product success in internal and alliance-based processes. Journal of Marketing, 64(1), 31-49.

Slater, S. F., \& Narver, J. C. (1994, March - April). Market orientation, customer value and superior performance. Business Horizons, 22-28.

Teece, D. J., Pisano, G., \& Shuen, A. (1997). Dynamic capabilities and strategic management. Strategic Management Journal, 18, 509-533.

Uzzi, B. (1997). Social structure and competition in interfirm networks: The paradox of embeddedness. Administrative Science Quarterly, 42(1), 37-70.

Venkatraman, N. (1989, August). Strategic orientation of business enterprises: The construct, dimensionality and measurement. Management Science, 35, 942-962.

Verhoef, P. C., \& Leeflang, P. S. H. (2009). Understanding the marketing department's influence within the firm. Journal of Marketing, 73, 14-37.

Vorhies, D. W., \& Harker, M. (2000). The capabilities and performance advantages of market-driven firms: An empirical investigation. Australian Journal of Management 25(2), 145-171.

Vorhies, D. W., Harker, M., \& Rao, C. P. (1999). The capabilities and performance advantages of market-driven firms. European Journal of Marketing, 33(11/12) $1171-1202$.

Ward, S., Girardi, A., \& Lewandowska, A. (2006). A cross-national validation of the Narver and Slater market orientation scale. Journal of Marketing Theory and Practice, 14(2), 155-167.

Webster, F. E. (1992). The changing role of marketing in the corporation. Journal of Marketing, 56, 1-17.

Weerawardena, J., \& O'Cass, A. (2004). Exploring the characteristics of the marketdriven firms and antecedents to sustained competitive advantage. Industria Marketing Management, 33, 419-428.

Wooldridge, B. R., \& Minsky, B. D. (2002). The role of climate and socialization in developing interfunctional coordination. The Learning Organization, 9(1), 29-38.

Wind, Y., \& Robertson, T. S. (1983). Marketing strategy: New directions for theory and research. Journal of Marketing, 47, 12-21. 
Yung-Ching, H., \& Tsui-Hsu, T. (2006). The impact of dynamic capabilities with market orientation and resource-based approaches on NPD project performance. The Journal of American Academy of Business, 8(1), 215-229.

Zhao, Y., \& Cavusgil, S. T. (2006). The effect of supplier's market orientation on manufacturer's trust. Industrial Marketing Management, 35, 405-414.

Zhou, K. Z., Brown, J. R., Dev, C. S., \& Agarwal, S. (2007). The effects of customer and competitor orientations on performance in global markets: A contingency analysis. Journal of International Business Studies, 38, 303-319.

Maria Smirnova is a Senior Lecturer at Saint Petersburg State University, Graduate School of Management. Her research interests include industrial marketing, relationship and interaction in business markets, international marketing and quantitative methods.

Peter Naudé is Professor of Marketing at Manchester Business School, University of Manchester. His area of interest is industrial marketing and is closely associated with the research themes of the IMP Group.
Stephan C. Henneberg is Professor of Marketing and Strategy at Manchester Business School, University of Manchester. His primary areas of research are in strategic marketing, relational and network marketing, and political marketing.

Stefanos Mouzas is a Reader/Associate Professor in Marketing at the Lancaster University Management School. His research interests include industrial marketing, negotiations and deal making.

Sergei Kouchtch is Associate Professor at Saint Petersburg State University, Graduate School of Management. His research interests are in industrial marketing, coordination of business relationships, and the interaction in business markets. 